Vol 2 (2) 2020, 33-39

\title{
Karakteristik Pertumbuhan Jamur pada Media PDA dengan Metode Pour Plate
}

\author{
Anang Juni Yastanto ${ }^{1}$ \\ 1Departemen Teknologi Pangan dan Hasil Pertanian, Fakultas Teknologi Pertanian, \\ Universitas Gadjah Mada, Yogyakarta, email : anankjunias@gmail.com
}

Submisi : 16 Agustus 2019; Penerimaan : 26 Februari 2020

\begin{abstract}
ABSTRAK
Jamur memerlukan oksigen untuk pertumbuhannya, sehingga jamur biasanya diinokulasi dengan cara spread plate (digores di permukaan media). Inokulasi juga bisa dilakukan dengan pour plate, yaitu dengan menambahkan mikrobia pada media agar sebelum memadat (suhu $45^{\circ} \mathrm{C}$ ). Kelemahan dengan metoda pour plate yaitu akan membatasi ketersediaan oksigen dalam medium yang dibutuhkan untuk pertumbuhan jamur. Tujuan dari penelitian ini yaitu 1) mengetahui pertumbuhan miselia jamur pada media secara pour plate, 2) mengetahui waktu inkubasi miselia jamur ketika muncul di permukaan media dan pembentukan spora jamur. Suspensi spora jamur Rhizopus oligosporus diplating dengan dua cara yaitu spread plate dan pour plate dengan menggunakan media PDA (Potato Dextrose Agar), kemudian diinkubasi suhu $30{ }^{\circ} \mathrm{C}$ selama 5 hari. Pengamatan dilakukan setiap hari dengan melihat pertumbuhan miselia dan pembentukan sporanya. Hasil menunjukkan bahwa Jamur dapat hidup dengan metoda pour plate dan menghasilkan miselia yang dapat menembus media untuk mencari oksigen. Spora jamur berkecambah di dalam media PDA pada inkubasi 12 jam dan dengan metode pour plate miselia akan muncul ke permukaan media pada inkubasi 24 jam. Setelah 48 jam inkubasi, miselia akan semakin menyebar dan mulai terbentuk sporangium pada kedua metode inokulasi. Spora hitam muncul pada inkubasi hari ke 3 dan akan merata pada inkubasi hari ke 5. Kecepatan pertumbuhan jamur yang ditumbuhkan dengan metoda pour plate tidak berbeda dengan jamur yang ditumbuhkan dengan metoda spread plate.
\end{abstract}

Kata kunci : pour plate; pertumbuhan; jamur; Rhizopus oligosporus.

\section{PENDAHULUAN}

Penelitian mikrobiologi tidak terlepas dari penggunaan mikrobia. Jamur yang sering dipakai untuk penelitian dan praktikum yaitu Aspergillus sp., Rhizopus sp. dan Trichoderma sp. Jamur biasanya untuk fermentasi substrat padat, cair dan melihat aktivitas enzim dari jamur tersebut. Sebelum fermentasi jamur ditumbuhkan pada media Potato Dextrose Agar (PDA) miring dan diinkubasi pada suhu $30{ }^{\circ} \mathrm{C}$ selama 7 hari. PDA miring dibuat dengan mendinginkan media setelah sterilisasi secara miring dengan menggunakan pipet (kemiringan $\pm 20^{\circ}$ ) hingga padat (Ptiwari, Hoondal, and Tewari 2009). Biasanya memerlukan waktu 12 jam supaya agar memadat secara sempurna sebelum digunakan. Setelah media agar memadat spora jamur diinokulasikan dengan ose bermata di permukaan media (Bykowski and Stevenson 2008). Inokulasi mikrobia selain dilakukan dengan spread plate, bisa juga dilakukan dengan pour plate. Pour plate merupakan cara inokulasi dengan mencampurkan mikrobia dengan media yang masih hangat $\left(45^{\circ} \mathrm{C}\right)$ kemudian didinginkan. (Jayashantha 2016) menyimpulkan bahwa enumerasi jamur 
dan yeast dengan metode pour plate tidak berbeda secara signifikan dibandingkan dengan metode spread plate. Sehingga metode pour plate kemungkinan bisa diaplikasikan untuk inokulasi jamur pada agar miring. Dengan teknik inokulasi ini diharapkan akan membuat pekerjaan lebih cepat dan efisien waktu tanpa harus mendiamkan media agar selama 12 jam. Tetapi dalam penelitian ini belum dijelaskan bagaimana pertumbuhan jamur di dalam media dengan metode pour plate. Sehingga penelitian yang akan dilakukan ini akan menjelaskan jamur bisa tumbuh di dalam media hingga muncul ke permukaan media.

Tujuan dari penelitian ini yaitu untuk mengetahui pertumbuhan miselia jamur pada media secara pour plate. Selain itu untuk mengetahui waktu inkubasi miselia jamur ketika muncul di permukaan media dan pembentukan spora jamur.

\section{METODE PENELITIAN}

Bahan : media PDA (Merck), tween 80, isolat R.oligosporus koleksi laboratorium Bioteknologi

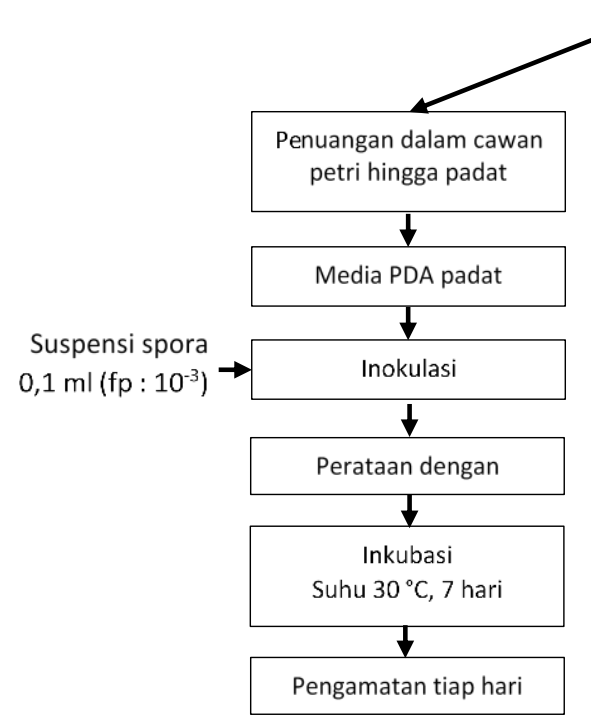

(Spread plate)
Alat : Autoklaf, Oven sterilisasi Memmert, cawan petri, tabung reaksi, mikroskop Olympus, inkubator $30{ }^{\circ} \mathrm{C}$, haemocytometer, tabung reaksi, timbangan

Prosedur penelitian :

1. Pembuatan media PDA

Serbuk PDA (Merck) ditimbang sebanyak $36,5 \mathrm{~g}$ dalam gelas piala, kemudian ditambahkan 1 liter akuades. Media dipanaskan hingga mendidih pada hotplate dan diaduk menggunakan stirrer. Media PDA yang sudah mendidih kemudian disterilisasi dengan autoklaf suhu $121^{\circ} \mathrm{C}$ selama 15 menit.

2. Pengenceran suspensi spora

Isolat dalam tabung reaksi ditambahkan tween 0,05\% steril dan diambil sporanya dengan ose bermata hingga diperoleh suspensi spora. Suspensi spora kemudian diencerkan dengan mengambil $1 \mathrm{ml}$ dimasukkan ke tween 0,05\% sebanyak $10 \mathrm{ml}$ (fp : $10^{-1}$ ). Pengenceran dilanjutkan hingga faktor pengenceran $10^{-4}$.

3. Inokulasi jamur pada media PDA Inokulasi jamur dilakukan dengan metode seperti pada Gambar 1.



(Pour plate)

Gambar 1. Gaftar alir inokulasi pada media PDA dengan kedua metode 
4. Pengamatan pertumbuhan jamur

Pertumbuhan miselia jamur pada media PDA diamati setiap hari dengan memfoto dari bidang pandang atas dan samping cawan petri. Pengamatan pertumbuhan miselia jamur di dalam agar dan pembentukan spora dilakukan dengan melihat secara langsung dengan mikroskop perbesaran 100x.

Tabel 1(a). Pengamatan visual pertumbuhan jamur Rhizopus oligosporus selama inkubasi dengan dua metode inokulasi



\section{HASIL DAN PEMBAHASAN}

Pengamatan secara visual dilakukan dari hari 0 hingga hari ke 5 inkubasi, dilihat dari atas dan samping seperti yang ditunjukaan pada Tabel 1 . Hal ini dilakukan untuk melihat pertumbuhan miselia dan pembentukan spora jamur. 
Tabel 1(b). Pengamatan visual pertumbuhan jamur Rhizopus oligosporus selama inkubasi dengan dua metode inokulasi

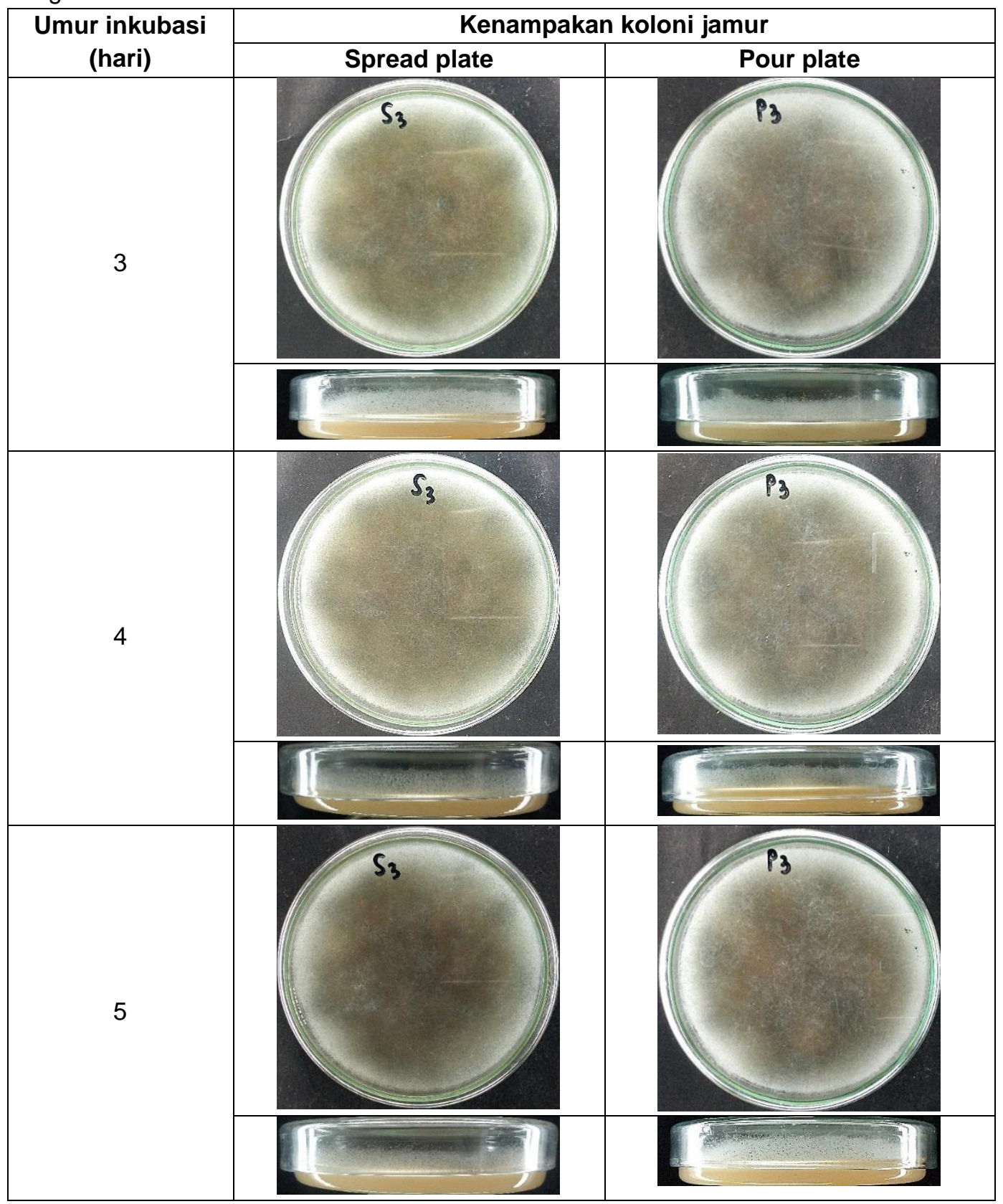

\section{Perkecambahan spora}

Pada penelitian ini sampel yang digunakan yaitu suspensi spora jamur Rhizopus oligosporus. Spora akan berkecambah jika kondisi pertumbuhannya mendukung, misalnya suhu, nutrisi, aw media dan oksigen. Jamur merupakan mikrobia dengan sifat tumbuh mesofil sehingga suhu optimal perkecambahan spora jamur yaitu 20-30 ${ }^{\circ} \mathrm{C}$. Hal ini sesuai dengan penelitian yang diinkubasi pada suhu $30^{\circ} \mathrm{C}$. Media PDA merupakan media yang dibuat dari umbi ekstrak umbi kentang karena mengandung nutrisi yang komplek seperti nitrogen, enzim, vitamin dan mineral. Jamur akan memecah pati dalam kentang menjadi gula terlarut yang 
dapat berfungsi sebagai sumber karbon dan energi (Wongjiratthiti and Yottakot 2017). Media PDA yang lengkap akan mendukung untuk perkecambahan spora jamur meskipun spora berada di dalam agar. Kadar air media dan aw media ditentukan oleh adanya air bebas yang bisa digunakan untuk metabolisme jamur. Kadar air bahan yang bisa ditumbuhi oleh jamur yaitu $>14 \%$ sedangkan aw minimal media untuk pertumbuhan jamur yaitu 0,8. Pada media ini tidak ada penambahan bahan untuk pengaturan air dan aw sehingga media PDA merupakan media yang baik untuk jamur. Oksigen juga sangat dibutuhkan untuk perkecambahan spora jamur meskipun dalam jumlah yang kecil. Karena jamur bersifat aerobik maka jika tidak terdapat oksigen spora tidak akan berkecambah. Pada inokulasi jamur secara pour plate spora tumbuh di dalam media pada pengamatan inkubasi 18 jam (Gambar 2a), hal ini menunjukkan bahwa di dalam media agar juga terdapat oksigen. Oksigen yang terdapat di dalam media PDA merupakan oksigen terlarut yang jumlahnya akan berkurang pada kedalaman tertentu. Berbeda dengan spora yang tumbuh di permukaan agar, kondisi untuk perkecambahan spora sangat mendukung sehingga miselia akan lebih banyak tumbuh seperti yang terlihat pada Gambar 2b.
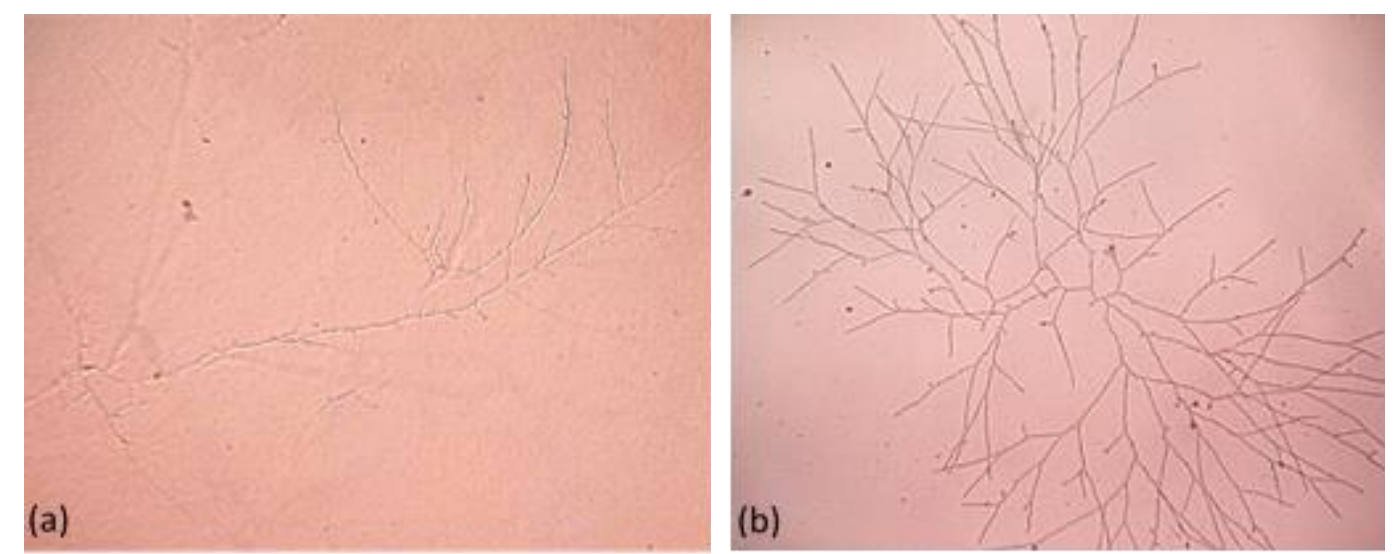

Gambar 2. Pengamatan perkecambahan spora jamur di dalam (a) dan di permukaan (b) media PDA pada inkubasi 18 jam

Keterangan : pengamatan dengan mikroskop langsung pada perbesaran $40 x$

\section{Pengamatan inkubasi 1 hari}

Koloni jamur sudah tumbuh dan terlihat masih sangat tipis untuk kedua cara inokulasi. Inokulasi secara pour plate koloni terdapat di dalam dan di permukaan media, sedangkan secara spread plate terdapat di permukaan media. Pada pengamatan pertumbuhan miselia inkubasi 24 jam terlihat bahwa miselia (metode pour plate) sudah muncul menembus agar. Gambar 3a dan Gambar 3b. menunjukkan foto miselia yang muncul dari dalam agar ke permukaan.
Oksigen di permukaan media lebih banyak dibandingkan di dalam media, sehingga miselia muncul ke permukaan dikarenakan jamur membutuhkan oksigen yang banyak untuk pertumbuhannya dan pembentukan sel vegetatif (spora). Jika jumlah oksigen kurang atau dibatasi miselia tidak akan membentuk spora. Sebagai contoh pada fermentasi tempe, spora akan muncul pada lubang plastik atau pada lipatan pada tempe yang dibungkus dengan daun karena daun pecah sehingga oksigen lebih banyak. 


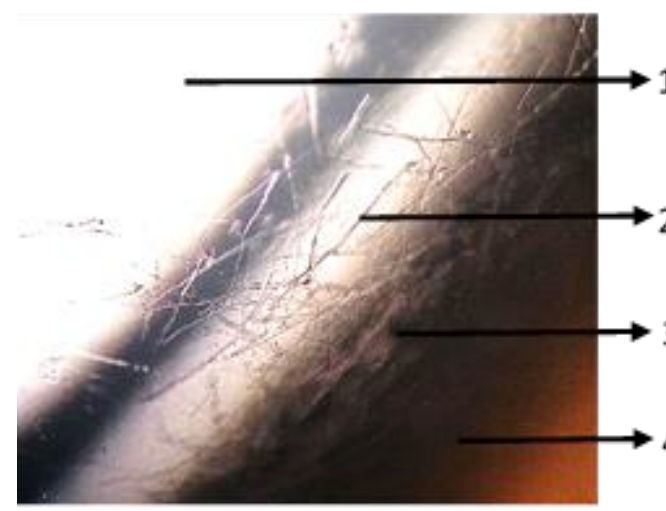

(a)

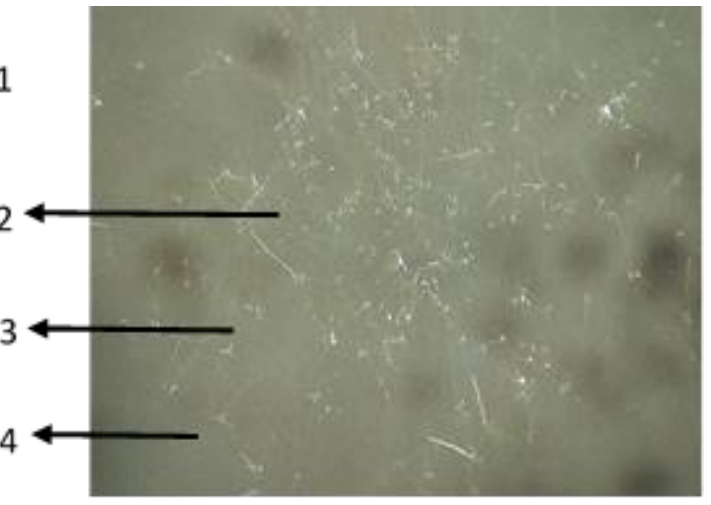

(b)

Gambar 3. Pengamatan munculnya miselia jamur ke permukaan media pada inkubasi 24 jam dari samping (a) dan atas (b)

Keterangan gambar : 1. Ruang udara 2. Miselia jamur di permukaan media 3.

Permukaan agar 4. Miselia jamur di dalam media

\section{Pengamatan inkubasi 2 hari}

Miselia jamur pada hari ke 2 sudah telihat tumbuh lebat berwarna putih menutupi cawan petri. Hal ini kemungkinan miselia jamur sudah menyebar ke seluruh permukaan media. Rhizopus oligosporus merupakan jamur yang memiliki hifa tidak bersepta sehingga pertumbuhannya lebih cepat dibandingkan jamur yang bersepta. Pengamatan jamur secara mikroskopik terlihat sudah terbentuk struktur jamur
Rhizopus sp secara utuh dengan sporangium masih berwarna putih (belum terdapat spora). Struktur jamur Rhizopus oligosporus dapat dilihat pada Gambar 4. Pada Gambar terlihat uap air yang menempel di miselia. Uap air ini terbentuk dari jamur terdapat yang dikeluarkan selama pertumbuhan. Jumlah uap air akan bertambah dengan bertambahnya waktu inkubasi.

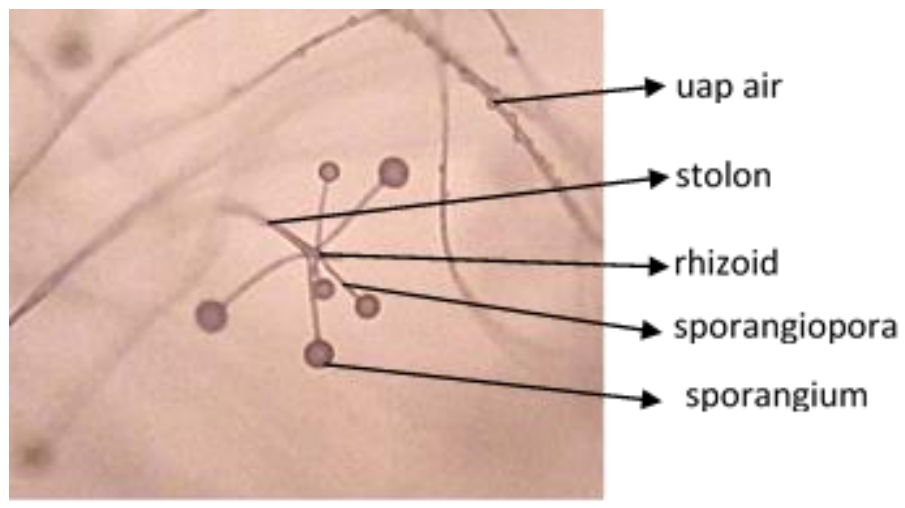

Gambar 4. Morfologi jamur Rhizopus oligosporus inkubasi 2 hari

\section{Pengamatan inkubasi 3-5 hari}

Spora jamur sudah terlihat merata pada inkubasi hari ke 3 dan akan semakin hitam pada hari ke 5 . Hal ini kemungkinan dikarenakan nutrisi di dalam media yang sudah habis dan oksigen yang berlebih. Jamur akan membentuk spora jika kondisi sudah tidak memungkinkan untuk hidup. 
Sehingga untuk mempertahankan kehidupan jamur akan membentuk spora. Jika spora berada dalam kondisi yang memungkinkan akan tumbuh Kenampakan spora jamur ditunjukkan pada Gambar 5.

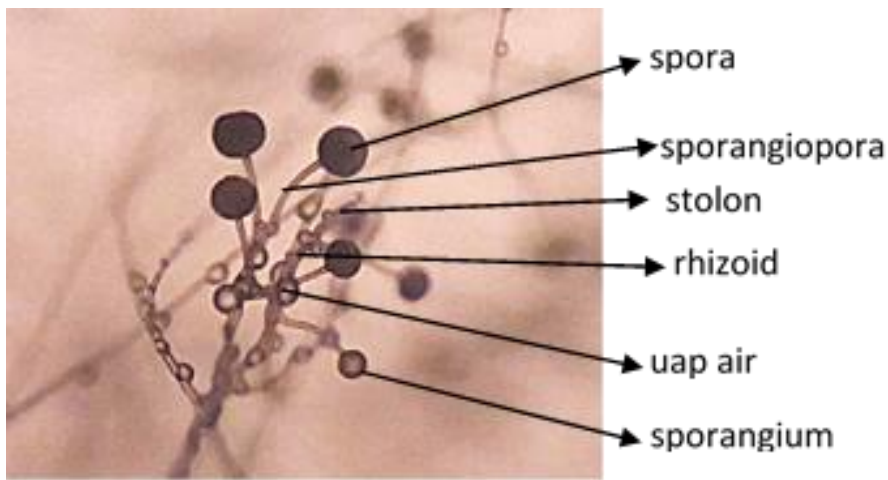

Gambar 5. Morfologi jamur Rhizopus oligosporus dengan spora mulai menghitam

\section{KESIMPULAN}

Setelah melakukan percobaan dapat disimpulkan bahwa jamur dapat hidup dengan metoda pour plate dan menghasilkan miselia yang dapat menembus media untuk mencari oksigen. Spora jamur berkecambah di dalam media PDA pada inkubasi 12 jam dan dengan metode pour plate miselia akan muncul ke permukaan media pada inkubasi 24 jam. Setelah 48 jam inkubasi, miselia akan semakin menyebar dan mulai terbentuk sporangium pada kedua metode inokulasi. Spora hitam muncul pada inkubasi hari ke 3 dan akan merata pada inkubasi hari ke 5. Kecepatan pertumbuhan jamur yang ditumbuhkan dengan metoda pour plate tidak berbeda dengan jamur yang ditumbuhkan dengan metoda spread plate.

\section{UCAPAN TERIMA KASIH}

Penulis mengucapkan terima kasih kepada Dr. Ir. Muhammad Nur Cahyanto, M.Sc selaku Ketua Departemen TPHP FTP UGM, Dr. Ir.
Tyas Utami M.Sc selaku Kepala Laboratorium Bioteknologi, Dr. Ir. Retno Indrati, M.Sc dan Prof. Dr. Ir. Sardjono, MS. yang telah membimbing dalam penelitian ini.

\section{DAFTAR PUSTAKA}

Bykowski, Tomasz, and Brian Stevenson. 2008. "Aseptic Technique." In Current Protocol in Microbiology, Wiley Intescience, 111.

Jayashantha, Eranga. 2016. "Herbs Using Different Techniques and Department of Microbiology." (December).

Ptiwari, R, S Hoondal, and R Tewari. 2009. Laboratory Techniques in Microbiologi \& Biotecnology. New Delhi: Mehra Offset.

Wongjiratthiti, A., and S. Yottakot. 2017. "Utilisation of Local Crops as Alternative Media for Fungal Growth." Pertanika Journal of Tropical Agricultural Science 40(2): 295-304. 